\title{
КУЛЬТУРНА СПЕЦИФІКА ФРАНКО-ІТАЛІЙСЬКОЇ ДРАМИ РАННЬОГО РОКОКО
}

\author{
Данченко Марія Леонідівна \\ Національний університет "Києво-Могилянська академія”, м. Київ, Украӥна, \\ ORCID ID: https://orcid.org/0000-0002-7846-9947
}

DOI: https://doi.org/10.31435/rsglobal_ijitss/30062020/7134

\section{ARTICLE INFO}

Received 18 April 2020

Accepted 14 June 2020

Published 30 June 2020

\section{KEYWORDS}

rococo,

Luigi Riccoboni,

Nouvelle Comédie-Italienne,

Théâtre-Italien.

\begin{abstract}
This article is dedicated to the issue of the genesis of literary rococo in FrenchItalian drama. In the following article we provide a brief review of theatrical activity of Italian troupes in 1660-1720s and explore the formation of new French-Italian stylistic and ideological concepts. Our research focuses particularly on the oeuvre of Luigi Riccoboni, a dramatist of Italian origin and Italian cultural background who wrote numerous scripts for the plays to be performed on French stage. With regard to the lack of studies of these FrenchItalian plays in Eastern Europe we provide an outline of Luigi Riccoboni's script for comedy "Le Libéral malgré lui" and analyze the intertwining of Italian and French cultural elements in this play. Our study contributes to global research of French rococo in Eastern Europe and explores the aspect of formation of literary rococo in the process of collaboration between French and Italian authors. This article offers a new interpretation of Luigi Riccoboni's oeuvre as that of the first representative of rococo style both in Italian and French literature.
\end{abstract}

Citation: Danchenko M. L. (2020) Cultural Specificity of French-Italian Drama in Early Rococo. International Journal of Innovative Technologies in Social Science. 5(26). doi: 10.31435/rsglobal_ijitss/30062020/7134

Copyright: (C) 2020 Danchenko M. L. This is an open-access article distributed under the terms of the Creative Commons Attribution License (CC BY). The use, distribution or reproduction in other forums is permitted, provided the original author(s) or licensor are credited and that the original publication in this journal is cited, in accordance with accepted academic practice. No use, distribution or reproduction is permitted which does not comply with these terms.

Вступ. Мандрівні трупи італійських акторів, які грали вистави в стилі традиційного італійського театру масок “del'arte”, з'явилися у Франції ще за правління Франциска I, а один з цих театрів, яку дослідники умовно називають “трупа Фйореллі-Локателлі”, маючи особливий успіх, з 1660 року починає давати регулярні вистави в Парижі. До початку 1680-х років італійські комедії виконувалися у класичній стилістичній техніці “del'arte”, але з 1684 року вони починають вставляти в свої діалоги речення французькою мовою, а потім - і цілі сцени [2, 98]. 31682 року трупу очолює Еварісто Герарді, який до того часу виконував роль Арлекіна, i він реформує саму концепцію Італійського театру, залучаючи до написання комедій авторівфранцузів: Франсуа Реньяра, Шарля Дюфресні, Анн Модюї де Фатувіля, Брюжьєра де Баранта та інших письменників, які адаптували свої сюжети під стилістично-рольові моделі італійського театру $[2,102]$. При цьому Еварісто Герарді сам продовжував писати сценарії для комедій, більшість яких не збереглися. В 1697 році за наказом короля цей колектив розпускають за звинуваченнями в непристойності сюжетів їхніх вистав, та акторських імпровізацій на сцені. Але справжньою причиною їхньої відставки вважається той факт, що в назві анонсу свого майбутнього спектаклю "La Fausse Prude" ${ }^{1}$ вони натякали на поведінку Франсуази де Ментенон, морганатичної дружини короля. Сам театр було ліквідовано, а деякі автори-французи, які писали п’єси для їхнього театру, перейшли до театру Французької комедії $[7,8]$. Однак успіх французьких п'єс, написаних для італійського театру, був таким великим, що Еварісто Герарді вже в 1698 році одержує від короля привілей на видавництво окремої

${ }^{1}$ Облудна чеснота 
збірки драматургії Італійської комедії. Збірка називалася "Théâtre italien, ou receuil de toutes les scènes françaises qui ont été jouées sur le théâtre italien de l'Hôtel de Bourgogne ${ }^{1 "}$. Концепція цього видання обурила колишніх акторів трупи, оскільки в ній були представлені майже винятково п’єси французьких авторів, які імітували стилістику Італійського театру, і серед них була лише одна комедія, створена самим Еварісто Герарді, але і та була написана французькою мовою. При цьому у текстах комедій деякі репліки героїв, особливо Арлекіна, писалися італійською мовою, або в них вставлялися італійські слова [с. 157]. Еварісто Герарді помер у 1700 році, невдовзі після виходу кількох перших томів збірки, але вона мала нечуваний успіх, і регулярно перевидавалася до 1741 року, що свідчить про значний резонанс, який викликала ця збірка як продукт ідеологічно-культурної співпраці італійських та французьких авторів. Через рік після смерті Людовіка XIV регент Франції Філіп Орлеанський вирішить знову відродити театр Італійської комедії, і запросить з цією метою до Франції італійську акторську трупу з Модени, яку очолював актор і драматург Луїджі Ріккобоні. Цей театральний колектив, який Луїджі Ріккобоні очолюватиме з 1716 по 1729 рік, одержить назву Другої Італійської комедії, а драматичні твори, які ставитимуть на їі сцені, дослідники вважатимуть класичними зразками літературного рококо у французькій драматургії.

Одним $з$ головних чинників формування стилю рококо, на нашу думку, були спроби синтетичного створення нових естетичних моделей шляхом свідомого поєднання культурностилістичних феноменів, що належали до традицій різних країн. Відтак, вивчення франкоіталійської драматургії останньої четверті XVII-першої третини XVIII століття має велике значення для дослідження проблеми становлення літературного рококо. В цій статті ми досліджуємо культурну специфіку франко-італійської драматургії Другої Італійської комедії на матеріалі творчості Луїджі Ріккобоні-одного 3 головних сценаристів період акторської та драматургічної діяльності якого припав на 1716-1729 роки. Мета даної статті - вивчити, яким чином у драматургічних сценаріях Луїджі Ріккобоні поєднувалися французькі та італійські культурно-стилістичні риси, та оцінити роль цієї культурної взаємодії у формуванні ідейних та естетичних засад літературного рококо у французькій драматургії. Актуальність даного дослідження зумовлена тим, що попри визначну роль творчого доробку Л. Ріккобоні у створенні і утвердженні естетики рококо у театрі, в Східній Свропі не існує перекладів його праць та досліджень його творчості. Луїджі Ріккобоні написав не лише багато комедійних сценаріїв, а i низку історичних праць, присвячених історії французького та італійського театру та кілька теоретичних трактатів, у яких порівнював техніки італійської та французької акторської гри.

Луїджі Ріккобоні народився в Модені, у родині відомого актора, який виконував амплуа Панталоне в театральній трупі при дворі герцога Модени. 3 ранніх років він захоплювався Мольєром та іншими французькими класиками, $i$, добре опанувавши французьку мову, навіть перекладав його твори на італійську. Після смерті батька він сам увійшов до акторського складу трупи, і під впливом французьких комедій створив власну, новітню концепцію італійської драматургії. Так, він вирішив обмежити роль акторської імпровізації, а натомість ставити спектаклі за творами відомих поетів, такими як "Софонісба" Тріссіно, чи "Едіп" Софокла $[1,309]$. Зі своїми виставами він навіть виїжджає до Венеції, але там публіка все ще віддана традиціям театру дельарте, відтак, новітня творчість Л. Ріккобоні не має там успіху. В 1716 році він одержує запрошення від Філіпа Орлеанського, регента Франції, з пропозицією привезти свою трупу до Парижа і відродити там театр Італійської комедії, який припинив свою діяльність у 1697 році. По приїзду до Парижа трупа Ріккобоні спершу намагається давати вистави італійською мовою. Сучасник, філософ і літературознавець Ніколя Буандан у своїх листах детально розповідає про приїзд італійців до Парижа, описує склад їхньої трупи, i говорить при цьому про самого Леліо наступним чином: “Lélio: fils d'un Comédien, est d'une taille avantageuse \& seroit assez bien fait s'il n'étoit pas un peu ensellé; il lui manque des graces Françoises: mais on espère que dans la suite il pourra les acquerir ${ }^{2 "}$ [1, 8]. В цьому ж джерелі автор зазначає, що вистави італійської комедії відразу мали величезний успіх, так що театр

\footnotetext{
${ }^{1}$ Італійський театр, або збірка всіх французьких п’єс, які грали в Італійському театрі в Отель Бургонь

${ }^{2}$ Леліо, син комедіанта, високого зросту, і можна було б назвати його гарно збудованим, якби в нього не було дещо вигнутого поперека, йому бракує французьких принад, але маю надію, що в майбутньому він їх набуде
} 
Французької комедії почав зазнавати збитків. Однак попри цей факт, у більшості публіки все одно були труднощі із розумінням італійської мови. За його словами, дехто із глядачів, хто краще знали італійську, сиділи в передніх рядах, і перекладали жарти акторів для тих, хто їх не розумів. Попит на всі підручники з італійської мови, книжки і словники після приїзду трупи Ріккобоні до Парижа зріс такою мірою, що книготорговці мали великі прибутки з їх продажів $[3,29]$. Однак при цьому за свідченням іншого сучасника, глядачі більше приваблювала акторська гра італійців з її імпровізаціями та хореографічними й вокальними елементами, ніж сюжет самих п'єс: “[Les spectateurs] étaient moins attentifs à suivre la conduite de l'intrigue; qu'à examiner le geste des Acteurs; la figure des Actrices \& leur manière de jouer qu'il comparait à celles de leurs Prédecesseurs" $"[5,194]$.

Така сприйняття французькою публікою його творчості не вдовольняло Луїджі Ріккобоні, адже він прагнув розвивати традиції італійського театру в напрямку психологізму, але він відразу побачив, що йому поки бракує такого письменницького досвіду. Відтак, попри те, що Луїджі Ріккобоні, досконало володів французькою мовою, і писав сценарії для вистав самостійно, він не міг повністю догодити смакам французької публіки, і у театру виникла потреба у залученні французьких авторів. Л. Ріккобонівже в 1716 році наймає для написання сценаріїв для п'єс різних авторів-французів, але при цьому сам не полишає спроб писати власні п’єси і ставити їх у своєму театрі. Так, дослідникЕ. Грін, в хронологічній таблиці, яка відображає репертуар новоствореної трупи Італійської комедії, крім п’єс самого Луїджі Ріккобоні, вказує твори французьких драматургів Ж. Отро, Ф. Койпеля, Ф. Детуша, Ф. Д’Аленсона [4, 186]. Крім того, сам Луїджі Ріккобоні виявляє інтерес до порівняння французької та італійської акторської техніки, про що свідчить написана ним вже в 1716 році п’єca "L'Italien françisé”, а згодом він присвятить цій темі кілька теоретичних трактатів. Попри наявність у трупі кількох французьких драматургів, у 1720 році Луїджі Ріккобоні приймає до складу сценаристів трупи молодого французького письменника П'єра Маріво, який створює низку французько-італійських комедій, героями яких були персонажі театру дель арте, склад яких вже змінився завдяки реформуванню його концепції Луїджі Ріккобоні, але в дії цих творів поєднувалися витончений французький психологізм та італійська невимушена грайливість. П’єси, написані П. Маріво для театру Другої Італійської комедії, вважатимуть класичним зразком стилю французького літературного рококо, але вплив Луїджі Ріккобоні на їх створення був настільки значним, що ми пропонуємо замінити термін “театр Маріво”, яким називають сукупність п’єс П’єра Маріво, на визначення “Театр Маріво-Ріккобоні”.

Ранні драматургічні роботи Ріккобоні були написані не у формі класичних п’єс, а у вигляді так званих “canevas" - текстів, в якому сюжет оповідки та приблизний зміст реплік персонажів детально описувався в прозовій формі, що давало акторам передбачену традицією італійського комічного театру можливість для імпровізації. Оскільки жоден твір Луїджі Ріккобоні не був перекладений у Східній Європі, ми вивчимо в даному дослідженні одну з його ранніх комедій 1717 року - "Lelibéral malgré lui", детально переказавши іiі зміст та виконавши іiі культурологічний аналіз.

Текст цього твору надрукований білінгвою: на сторінці зліва написано італійський текст, а на правій - його французький відповідник. Варто зазначити той факт, що Луїджі Ріккобоні досконало володів французькою мовою, але при цьому від самого свого прибуття до Франції він наймав французьких авторів, які писали п’єси для італійської акторської трупи. При цьому сам Луїджі Ріккобоні продовжував самостійно створювати сюжети для комедій, хоча, згідно з дослідженням філологів, вкрай мало його сюжетних нарисів були поставлені на сцені. Особливої уваги заслуговує сюжет комедії. Так, дійовими особами є персонажі театру дель арте: Панталоне, скупий батько, дві його доньки - Фламінія та Сильвія, двоє закоханих в них молодих дворян - Леліо та Маріо, їхні лакеї Арлекін та Скапен, і служниці дівчат Віолетта й Брюнетта і лакей Скарамуш, а також гурт навколишніх селян. П'єса починається із того, що Леліо скаржиться своєму слузі Скапену на нестерпну нудьгу від перебування в провінції, куди йому довелося приїхати через те, що тут він може побачити Фламінію, свою кохану дівчину,

\footnotetext{
${ }^{1}$ Глядачі менше виявляли уваги до того, щоб стежити за розвитком інтриги, як до того, щоб роздивлятися манеру гри акторів, до акторок і їх способу гри, яку вони порівнювали з грою їхніх попередниць.

${ }^{2}$ Марнотратник всупереч власній волі
} 
чий батько, скупий багатій Панталоне, приїде сюди з Парижа для того, аби зменшити витрати. Лакей радить господарю попросити у Панталоне руки його дочки, але Леліо згадує про те, що йдуть чутки, ніби Панталоне намагається видати доньок за багатих селян для того, аби не платити посаг. Панталоне дійсно привозить дочок у провінцію, і наказує слугам не приймати гостей та відвідувачів. Леліо зустрічає свого друга Маріо, який закоханий у іншу доньку Панталоне, Сильвію, і теж хотів би до неї посвататися, і той підтверджує чутки про плани батька віддати доньок заміж за селян. Фламінія зустрічається з Леліо, і говорить 3 ним про їхнє кохання - вони давно між собою знайомі. Коли вона повертається додому, іiі сестра Сильвія дошкуляє їй тим, що їі ніколи не можна застати вдома, а Фламінія безжурно каже ій, що була зі своїм коханим, за якого хоче вийти заміж. Вражена Сильвія переконує сестру, що шлюб - це каторга для жінки. Тим часом молоді кавалери вдаються до хитрощів, і Леліо приходить 3 візитом до Панталоне, сердечно його вітаючи, і видаючи себе за маркіза Бельфйоре, близького друга сина Панталоне Оттавіо, який зараз в складі свого полку воює десь у Фландрії. Леліо каже батькові Фламінії, що його син Оттавіо запрошував його погостювати у батьківському маєтку з місяць, але вони якимось чином розминулися, так що він волів би лишитися в себе, якби не наполегливі запрошення двох чарівних дівчат, які назвалися сестрами Оттавіо. Поміщик, який нещодавно і справді одержав листа від сина після його трирічної мовчанки, запрошує Леліо до себе. Тут-таки слуги повідомляють господарю дому про іншого відвідувача - це був Маріо, який видавав себе за сусіда-поміщика, що під час полювання поранив зайця, i той сховався у парку маєтку Панталоне, і просить дозволу його пошукати. Леліо і Маріо роблять вигляд, що впізнали один одного, обіймаються, і називають себе графом і маркізом. Леліо рекомендує другові, який назвався графом Лікідо, Панталоне як гостинного і щедрого багатія, і зрештою, господарю доводиться запросити до себе й Маріо. Обурений Панталоне сварить доньок, обіцяючи одружитися вдруге, і змусити їх слухатися мачуху. Кавалери врешті зустрічаються 3 дівчатами в саду, і ті готують для них розкішну трапезу. Панталоне йде за доньками назирці, і вони, помітивши його, запрошують приєднатися до товариства, на що він зрештою погоджується. Слуги тим часом повідомляють поміщику, що місцеві селяни, довідавшись про свято в його саду, прийшли туди 3 музичними інструментами, щоб влаштувати бал. Селяни і собі приєднуються до трапези, кавалери танцюють 3 дівчатами, i, зрештою, змушують танцювати й господаря. Насамкінець, через місяць Панталоне грубо випроваджує гостей, а спритний лакей Скапен радить своєму господарю, як можна знову проникнути в дім Панталон5. Так, господар дійсно хотів видати Сильвію заміж за якогось багатого селянина метра Паскаля, навіть не знаючи, як той виглядає. Скарамуш попереджає Фламінію про їхні плани, а та вирішує поки не говорити сестрі про те, що Маріо в неї закоханий, i каже їй, що її наречений метр Паскаль вже їде до неї. Панталоне повідомляють про приїзд його майбутнього зятя, і Скапен, переодягнений лакеєм метра Паскаля, каже йому, що господар почав у своєму будинку ремонт перед весіллям, так що жити там тепер ніяк, і тому разом $з$ усіми своїми слугами, собаками й майном їде до майбутнього тестя. Панталоне 3 доньками виїжджають їм назустріч. Роль метра Паскаля грає Арлекін, який вдає 3 себе неотесаного селюка, і показує Сільвії свої плуги та інший господарський реманент. Раптом Арлекін звертає увагу на служницю Віолетту, яка йому давно подобалася, і починає виявляти до неї грубі знаки уваги. Обурений Панталоне сварить його, на що той відказує, що то такий сільський звичай, пускається з селянами до танцю, і зрештою полишає товариство. Панталоне розриває доньчині заручини, і до нього приходить новий гість, який називає себе турецьким послом. Це переодягнутий Скапен, який говорить Панталоне про те, що його володар, король Мароко, подорожуючи Європою, зупинився у володіннях Панталоне, хоче запросити до себе на обід когось із місцевих статечних осіб, і таким $є$ він, господар маєтку. Разом з доньками він йде у парк, де його приймає переодягнутий у східний одяг Арлекін, а рабів "мароканського короля" зображають Леліо й Маріо. Скапен із задоволенням притискає Панталоне носом до землі у присутності короля, а монарх тим часом цілує його доньок. Слуги подають їм їжу, танцюючи при цьому, а король дарує мароканське шляхетство Панталоне і його донькам ${ }^{1}[9,58]$, а слуги одягають Панталонев розкішний турецький костюм. Гордий чоловік повертається додому, вимагає від слуг поштивішого ставлення $з$ огляду на свій новий високий статус, а його доньки

${ }^{1}$ Gentilhommeтa gentille-donnes 
починають говорити про те, які вони замовили екіпажі і нову розкішну обстановку для дому. Панталоне обурюється таким майбутнім витратам, і наказує Скарамушеві передати королю, що відмовляється від його шляхетства. Доньки натомість відмовляються це робити, і слуга повідомляє, що до них прибули нові слуги для їх Високостей принцес Мароканських. Слугами $\epsilon$ переодягнуті Леліо й Маріо, і вони ж називають і ціни за нову обстановку, яку вже скоро мають доставити, і дарують принцесам двох рабів - євнуха й мавра. Панталоне огидна навіть думка про те, щоб тримати в своєму домі таких чудовиськ, але він нічого не може вдіяти. Раби падають перед дівчатами навколішки. Розгніваний батько йде до себе, а слуги зізнаються дівчатам, що вони - Леліо й Маріо, а Сильвії сестра радить радше прийняти пропозицію закоханого дворянина, аніж іï віддадуть заміж за якогось селюка, на що остання зрештою погоджується. Фламінія всіх запрошує в сад пригоститися молодим вином. Панталоне проганяє Скапена й Арлекіна, i, дізнавшись, що його доньки знову щось із кимось святкують в саду, рішуче йде туди, маючи намір повернутися в місто, бо шляхетство обходиться йому надто дорого. Скарамуш повертається до господаря і говорить йому, що не знайшов короля Марокко, а якийсь селянин пояснив йому, що це все було чиєюсь вигадкою. Кавалери, дами і слуги п’ють вино у їдальні, розлючений Панталоне вривається туди зі зброєю, і погрожує вбити обманщиків-дворян та своїх розпусних доньок, а заодно покарати і селян, які допомагали їм у всіх цих витівках. Скапен бере на себе провину за всі ці події, а Леліо каже чоловікові, що це його жадоба призвела $є$ причиною всіх цих подій - він би не наважився свататись, бо знав, що йому напевне відмовлять, а Маріо говорить, що хотів пересвідчитись у тому, що Сильвія має до нього якісь почуття. Скапен на додачу заявляе, що якби господар дому не погодився на шлюб, то він знайшов би спосіб повністю його розорити. Панталоне не лишається нічого іншого, як погодитися на заміжжя своїх доньок. Всі святкують, співають і танцюють.

В цій комедії Луїджі Ріккобоні поєднує італійський та французький культурні контексти. Так, він не лише робить головними дійовими особами персонажів традиційного італійського театру, а й надає своїм героям ті ментальні риси, які не були властивими для персонажів французького театру. Зокрема, Фламінія і Сильвія вільно говорять про кохання, а Фламінія взагалі називає Леліо "amant" ${ }^{1}[9,17]$, що було б неможливим у французькій драматургічній традиції. Дівчата вільно висловлюють свої погляди на шлюб, і самі обирають із кількох чоловіків того, хто їм більше подобається, i, як ми можемо бачити з оповідки, вони лишаються з чоловіками наодинці, разом виходять в сад і пригощаються вином, що нагадує радше традиції італійських ренесансних оповідок, а не французької комічної драматургії. Доньки Панталоне і їхні наречені не просто намагаються умовити його одружити їх, а ще й всіляко дошкуляють йому і висміюють його, що цілком відповідає тій ролі, яку в італійському комічному театрі грає Панталоне - там він має амплуа скупого і ревнивого чоловіка, якого обманює дружина. При цьому сюжетний мотив, коли доньку аристократа віддають заміж за селюка, якого батько нареченої ніколи не бачив, має суто французьке походження, оскільки $\epsilon$ прямо запозиченим із п’єси Мольєра “Месьє де Пурсоньяк”, відтак, його можна вважати типово французьким культурним елементом. Гурт місцевих селян бере активну роль у дії, граючи роль хору, тоді як у французькій комедії група простолюдинів не могла виступати в якості повноцінних дійових осіб. Спритні слуги, які були посередниками в любовних справах своїх панів, могли бути героями п’єс у французьких драматургів - так, Ж.-Б. Мольєр використовує такий сюжетний хід, але для французької драматургії явище, коли слуга переодягається в одяг свого пана, типовим не є. Тим часом в італійських комедіях ми неодноразово зустрічаємо мотив, коли слуга і пан міняються одягом, і один видає себе за іншого. Сцена дарування Панталоне дворянства від мароканського короля в точності відтворює мольєрівський мотив посвячення в мамамуші міщанина Журдена, але при цьому в Мольєра незаміжні дівчата не брали участі в таких сміховинних забавах. А у Луїджі Ріккобоні Фламінія й Сильвія виступають спільницями своїх наречених i, знаючи про їхні намагання завдати Панталоне якомога більших збитків, плетуть інтриги проти власного батька. Коли ж той зрештою викриває обман, він поводиться не як французький комедійний герой, а відразу береться до зброї і клянеться всім помститися. Молоді люди натомість не просять пробачення в обдуреного господаря дому, а відверто і жорстоко кажуть йому про те, що не могли вчинити з ним інакше

${ }^{1}$ Коханець 
через його жадобу. Це суперечить тому, як французькі автори виражали мораль у своїх комічних п'єсах. Скапен зрештою навіть обіцяє йому, що якби він не змінив своїх рішень із приводу дочок, то вони б знайшли спосіб покарати його за жадібність. Відтак, мораль п'єси проголошується прямо - скуп'яг, які псують майбутнє своїх дітей, треба карати. Автор ніяк не дозволяє Панталоне відповісти на цю погрозу - на цьому оповідка закінчується, і всі святкують щасливий фінал з піснями і танцями. В додатку до п’єси Л. Ріккобоні подає тексти пісень, які співають герої у проміжках між актами, італійською й французькою мовами.

Л. Ріккобоні не лише запозичував сюжети 3 французьких п’єс, а й розширював культурно-рольове амплуа героїв традиційного італійського театру. Наприклад, роль Арлекіна в трупі Другої Італійської комедії виконував Томазо Візентіні, який у своїх імпровізаціях намагався викликати у глядачів не лише сміх, а і сльози співчуття, коли цього потребував сюжет [6, 77]. Згодом це нове розуміння ролі Арлекіна, яке з'явилося в італо-французькій комедії завдяки Т. Візентіні, буде розвинуто вже в комедіях Ф. Маріво, які цей письменник створював для театру Л. Ріккобоні.

Висновки. Як ми можемо побачити, Луїджі Ріккобоні почав розвивати концепцію реформи італійської драматургії ще в період свого перебування в Італії, намагаючись додати у італійські драми психологізм та більшу сюжетну варіабельність. Однак по прибуттю його театральної трупи у Францію виявилося, що творчих зусиль самого драматурга було недостатньо для того, аби французька публіка цінувала не акторську гру італійців, а саме зміст італійських комедій. Відтак, Луїджі Ріккобоні цілеспрямовано почав розвивати концепцію нової комедії, в якій мали поєднуватися французький психологізм і витонченість персонажів та італійська невимушеність ситуацій, заради чого залучив до співпраці кількох французьких драматургів, найвідомішим 3 яких був П'єр Маріво. Результатом спільної діяльності французьких та італійських драматургів стало утворення стилю рококо у французькій драматургії, та трансформація італійських культурних елементів у символи рокайлю.

При цьому Луїджі Ріккобоні ретельно вивчав французьку драматургічну та акторську техніку та намагався адаптувати французькі сюжети в свої твори. У спробах такої адаптації драматург перш за все орієнтувався на творчість Ж.-Б. Мольєра. При цьому на відміну від драматургії Першої Італійської комедії Луїджі Ріккобоні не намагається додавати італійські репліки і сцени у свої французькі комедії, а пише їх два варіанти різними мовами, і намагається апелювати до італійського культурного контексту в своїх творах за допомогою сюжетних особливостей, нетрадиційних для французького комічного театру. Відтак, на нашу думку, Луїджі Ріккобоні можна вважати засновником жанру франко-італійської драми рококо.

\section{ЛIТЕРАТУРА}

1. Boindin N. (1717) Lettres historiques à Mr $\mathrm{D}^{* * *}$ sur la Nouvelle Comédie Italienne. Dans lesquelles il est parlé de son Etablissement, du Caractère, des Acteurs qui la composent, des Pièces qu'ils ont representées jusqu'à present, \& des Avantures qui y sont arrivées. Première lettre: 3 tomes en 1 volume. Paris, Pierre Prault, 1717. P. 3-44. Retrieved from: https://gallica.bnf.fr/ark:/12148/bpt6k1087343/f47.image.

2. Duchartre P. L. (2012) The Italian Comedy: monograph. Trans. by R. T. Weaver. New York: Dover Publications, Inc. (In English) Retrieved https://books.google.com.ua/books?id=OvfBAgAAQBAJ\&pg=PA115\&dq=marivaux+riccoboni\&hl=uk\&s $\mathrm{a}=\mathrm{X} \&$ ved $=0$ ahUKEwirl -

3ryojqAhVLpYsKHb35Bo4Q6AEIMjAB\#v=onepage $\& \mathrm{q}=$ marivaux\%20riccoboni\&f=false

3. Gherardi E. (1741) Le Rétour de la Foire de Bezons. In Le théâtre Italien de Gherardi ou le recueil général de toutes les Comédies \& scénes françoises jouées par les Comediens Italiens du Roy, pendant tout le temps qu'ils ont été au service. Tome sixième. Paris, Briasson, rue Saint Jacques, à la Science. P. 155-202. Retrieved from: https://books.google.com.ua/books?id=0JGKdB95wgC\&pg=PA202\&lpg=PA202\&dq=Gherardi+E.+Le+R\%C3\%A9tour+de+la+Foire+de+Bezons.\&source= bl\&ots=QpLSx6NPet\&sig=ACfU3U1kuAYXAs2HGVlaK_tP3cAl_aiszA\&hl=uk\&sa=X\&ved=2ahUKEwi PqcG4zYjqAhVuoosKHVOiCsQQ6AEwA3oECAoQAQ\#v=onepage\&q=Gherardi\%20E.\%20Le\%20R\%C 3\%A9tour\%20de\%20la\%20Foire\%20de\%20Bezons.\&f=false

4. Greene E. J. H., Greene G. H. (1977) Menander to Marivaux: The History of a Comic Structure; monograph. Edmonton the university of Alberta Press Retrieved from: https://books.google.com.ua/books?id=_6PIMNyYn-

4C\&dq=marivaux+riccoboni\&hl=uk\&source=gbs_navlinks_s 
5. Klees H. (2011) Das Spiel in Comédie-Italienne (1662-1729): Strukturen und Funktionen im Wandel: Monographie. Würzburg: Königshausen\&Neumann. Retrieved from: https://books.google.com.ua/books?id=BIjKAwAAQBAJ\&printsec=frontcover\&dq=Klees+H.+(2011)+Das+Sp iel+in+Com\%C3\%A9die-Italienne+(1662-

1729):+Strukturen+und+Funktionen+im+Wandel\&hl=uk\&sa=X\&ved=0ahUKEwie0oKLz4jqAhVhtIsKHfL4A PUQ6AEIJzAA\#v=onepage\&q=Klees\%20H.\%20(2011)\%20Das\%20Spiel\%20in\%20Com\%C3\%A9dieItalienne\%20(1662-1729)\%3A\%20Strukturen\%20und\%20Funktionen\%20im\%20Wandel\&f=false

6. Nye E. (2011) Mime, Music and Drama on the Eighteenth-Century Stage: The Ballet d'Action: monograph. Cambridge: Cambridge University Press. Retrieved https://books.google.com.ua/books?id=wfAd0WW_0yYC\&pg=PR9\&dq=Nye+E.+(2011)+Mime,+Music+ and+Drama+on+the+Eighteenth-

Century+Stage:+The+Ballet+d\%E2\%80\%99Action\&hl=uk\&sa=X\&ved=2ahUKEwjMosqh7JfqAhUrw8Q BHcPkDuAQ6AEwAHoECAAQAg\#v=onepage \&q=Nye\%20E.\%20(2011)\%20Mime\%2C\%20Music\%20a nd\%20Drama\%20on\%20the\%20EighteenthCentury $\% 20$ Stage $\% 3 \mathrm{~A} \% 20 \mathrm{The} \% 20 \mathrm{Ballet} \% 20 \mathrm{~d} \% \mathrm{E} 2 \% 80 \% 99$ Action $\& \mathrm{f}=$ false

7. Poitevin O. (1970) Le théâtre de la foire, la comédie Italienne et l'opéra-comique recueil des pièces choisies, jouées de la fin du 17 siècle aux premières années du 19 siècle, avec étude historique, notes et table chronologique: monographie. Genève: Slatkin reprints. Retrieved from: https://books.google.com.ua/books?id=Xs4fqFMjisC \&printsec=frontcover\&hl=uk\&source=gbs_ge_summary_r\&cad=0\#v=onepage \&q\&f=false

8. Ravel J. S. (2018) The Contested Parterre Public Theater and French Political Culture, 1680-1791: monograph. London: Cornell University Press. Retrieved from: https://books.google.com.ua/books?id=_FluDwAAQBAJ\&printsec=frontcover\&hl=uk\&source=gbs_ge_su mmary_r\&cad $=0 \# \mathrm{v}=$ onepage $\& \mathrm{q} \& \mathrm{f}=$ false

9. Riccoboni L. (1729) Le Libéral Malgré Lui. In Le nouveau théâtre italien ou recueil général des comédies. Tome seconde. Paris: Briasson, rue Saint Jacques, à la Science. P. 2-78. Retrieved from: https://books.google.com.ua/books?id=ISlaAAAAcAAJ\&pg=PA11\&lpg=PA11\&dq=Le+nouveau+th\%C3\%A9 $\% \mathrm{C} 3 \% \mathrm{~A} 2$ tre+italien+ou+recueil $+\mathrm{g} \% \mathrm{C} 3 \% \mathrm{~A} 9 \mathrm{n} \% \mathrm{C} 3 \% \mathrm{~A} 9 \mathrm{ral}+\mathrm{des}+$ comedies.+Tome+seconde.\&source=bl\&ots=F tgiufCevk\&sig=ACfU3U14RKUyUxkUJW6AeDkhOe4euYouEw\&hl=uk\&sa=X\&ved=2ahUKEwi5k9fKzojq AhVOx4sKHYJKCCkQ6AEwAXoECAoQAQ\#v=onepage\&q=Le\%20nouveau\%20th\%C3\%A9\%C3\%A2tre\% 20italien\%20ou\%20recueil $\% 20 \mathrm{~g} \% \mathrm{C} 3 \%$ A9n\%C3\%A9ral\%20des\%20comedies.\%20Tome $\% 20$ seconde.\&f=false

10. Tessari R. (1995) Teatro e Spettacolo nel Settecento: monograph. Bari-Roma: Editori Laterza. Retrieved from: https://books.google.com.ua/books?id=WE9tDwAAQBAJ\&pg=PT126\&dq=Tessari+R.+Teatro+e+Spettacolo+ nel+Settecento\&hl=uk\&sa=X\&ved=2ahUKEwi89uDZ7JfqAhUD0qYKHU01BgIQ6AEwAHoECAYQAg\#v=o nepage $\&$ q=Tessari\%20R.\%20Teatro\%20e\%20Spettacolo $\% 20$ nel $\% 20$ Settecento $\& \mathrm{f}=$ false 